\title{
Sejarah Pemikiran Psikologi Islam Zakiah Daradjat
}

\author{
Nunzairina \\ Dosen Prodi Sejarah Peradaban Islam UIN Sumatera Utara \\ nunzairina@uinsu.ac.id
}

\begin{abstract}
Speaking of Islamic Psychology in Indonesia, it can not be separated from Zakiah Daradjat's contribution. He is an early figure who brought and developed Islamic Psychology in Indonesia. In addition to being an outstanding lecturer at several universities, his contribution is also reflected through his works. Scientists from Bukittinggi argue that Islamic psychology is closely related to Islamic education and mental health. and piety. Based on the uniqueness, this research will discuss related biography Zakiah Daradjat and his thinking about Islamic psychology. This study uses historical research methods with heuristic stages, verification, interpretation, and historiography. The results of this study is Zakiah Daradjat who was born on 6 November 1926 is the first Muslim psychologist in Indonesia who contribute greatly in the world of psychology and Islamic education. His contribution can be seen from his efforts and his work in these two fields. he argues that Islamic education has a close relationship with religious psiology and mental health. Bad phenomena that occur in the world of education today, will be overcome by using religious psychology as an approach in Islamic education. Thus, students will create mental health based on religion.
\end{abstract}

Keywords: Thought, Zakiah Daradjat, Islamic Psychology.

\begin{abstract}
Abstrak
Berbicara mengenai Psikologi Islam di Indonesia, maka tidak dapat dipisahkan dari kontribusi Zakiah Daradjat. Ia merupakan tokoh awal yang membawa dan mengembangkan Psikologi Islam di Indonesia. Selain menjadi dosen luar biasa di beberapa universitas, kontribusinya juga tercermin melalui karya-karyanya. Ilmuwan yang berasal dari Bukittinggi ini berpendapat bahwa psikologi Islam sangat erat kaitannya dengan pendidikan Islam dan kesehatan mental. dan takwa. Berdasarkan keunikan tersebut, maka penelitian ini akan membahas terkait biografi Zakiah Daradjat dan pemikirannya tentang psikologi Islam. Penelitian ini menggunakan metode penelitian sejarah dengan tahap-tahap heuristic, verifikasi, interpretasi, dan historiografi. Adapun hasil dari penelitian ini yaitu Zakiah Daradjat yang dilahirkan pada 6 November 1926 merupakan psikolog muslimah pertama di Indonesia yang berkontribusi besar dalam dunia psikologi dan pendidikan Islam. Kontribusinya dapat dilihat dari usahausaha dan karyanya di dua bidang tersebut. ia berpendapat bahwa pendidikan Islam memiliki kaitan erat dengan psiologi agama dan kesehatan mental. Fenomena-fenomena buruk yang terjadi di dunia pendidikan saat ini, akan dapat diatasi dengan menggunakan psikologi agama sebagai pendekatan dalam pendidikan Islam. Dengan demikian, akan tercipta para siswa yang mememiliki kesehatan mental yang berlandaskan pada agama.
\end{abstract}

Kata kucni: Pemikiran, Zakiah Daradjat, Psikologi Islam. 


\section{PENDAHULUAN}

Psikologi $^{1}$ agama $^{2}$ atau psikologi Islam merupakan suatu cabang ilmu pengetahuan yang lahir dari ilmu psikologi itu sendiri. Psikologi itu sendiri merupakan suatu disiplin ilmu pengetahuan yang mempelajari manusia. Psikologi didefinisikan sebagai The Scientific Study of Behavior and Mental Processes, yang berarti studi ilmiah mengenai proses perilaku dan proses mental. Psikologi juga dapat diartikan sebagai The Science of Human and Animal Behavior, it Includes the Application of This Science to Human Problem, yaitu ilmu yang mempelajari tingkah laku manusia dan hewan, hal ini meliputi penerapan ilmunya pada masalah-masalah manusia.

Psikologi merupakan suatu cabang ilmu pengetahuan yang terbilang masih baru dan diakui pada akhir abad ke-18 M. Hal ini berawal ketika Wilhelm Wundt (1832-1920) ${ }^{3}$ memiliki ketertarikan pada bidang fisiologi. Wundt kemudian melakukan pendekatan eksprimental dalam pendekatan studi psikologi. ${ }^{4}$ Psikologi ini terus mengalami perkembangan. Keadaan inilah yang kemudian mengantarkan lahirnya psikologi Islam.

Menurut Abdul Mujib dan Yusuf, psikologi Islam lahir sebagai reaksi dari kemajuan diskursus psikologi barat kontemporer. Reaksi tersebut semakin memuncak setelah hasil psikologi barat kontemporer yang bersifat antroposentris dan netral etik dijadikan sebagai "pisau analisis" dalam memahami fenomena psikologis masyarakat Islam yang teosentris dan sarat etik. ${ }^{5}$ Dengan demikian hal ini mengakibatkan benturan-benturan tersendiri yang akhirnya mengaharuskan ilmuwan-ilmuwan muslim juga berkiprah

${ }^{1}$ Istilah Psikologi berasal dari kata psycho dipakai dalam konstruk kata psikologi (psychology) berasal dari bahasa Yunani, psyche yang berarti "napas kehidupan". Berdasarkan mitologi Yunani, jiwa digambarkan sebagai kupu-kupu. Dalam hal ini kupu-kupu merupakan metafora bebas terbang setelah kepompong menempa diri dengan puasa lalu keluar dari bungkus kepompong tersebut. oleh karena itu, mempelajari psikologi merupakan kajian yang estetis, dinamis, dan penuh keajaiban. Lihat Bahril Hidayati, "Psikologi Islam", Fakultas Psikologi Universitas Negeri Sultan Syarif Pekanbaru-Riau, 2014, hlm. 4. Pendapat lain mengatakan bahwa psikologi berasal dari dua suku kata, yaitu psyche yang berarti "jiwa", dan logos yang berarti "ilmu".

${ }^{2}$ Agama berasal dari kata Sanskrit. Sebuah pendapat mengatakan bahwa kata tersebut tersusun dari dua kata, yaitu a yang berarti "tidak", dan gam yang berarti "pergi". Dengan demikian, agama diartikan sebagai sesuatu yang tidak pergi, tetap di tempat, dan diwarisi secara turun-temurun. Pendapat lain mengatakan bahwa agama adalah teks atau kitab suci. Lihat Harun Nasution, Islam Ditinjau Dari Berbagai Aspek Jilid I (Jakarta: UI Press, 2011), hlm. 1

${ }^{3}$ Wilhelm Wundt dilahirkan di Neckarau, Baden, Jerman. Ia berasal dari keluarga intelektual yang dipandang sebagai pendiri psikologi secara ilmiah. Wundt menamatkan studi kesarjanaannya dan memperoleh gelar Doctor di bidang kedokteran dan tertarik pada penelitian-penelitian fisiologis. Ia memperoleh posisi sebagai professor dan mengajar di Universitas Leipzig dan mendirikan Psychological Institute pada tahun 1879. Inilah yang tandai sebagai awal mula berdirinya Psikologi sebagai sebuah disiplin ilmu pengetahuan. Lihat Bahril Hidayat, "Psikologi Islam", hlm. 7.

"James F. Brennan, History And System of Psychology, diterjemahkan oleh Nurmala Sari Fajar, Sejarah dan Sistem Psikologi (Jakarta: Raja Wali Pers, 2006), hlm. 231.

${ }^{5}$ Abdul Mujib dan Yusuf Mudzakir, Nuansa-Nuansa Psikologi Islam (Jakarta: Rajawali Pers, 2002), hlm. 12. 
dalam bidang psikologi yang nantinya lebih dikenal dengan nama Psikologi Islam atau psikologi agama.

Adapun terkait definisi dari psikologi Islam, beberapa tokoh berbeda pendapat. Menurut Ancok dan Suroso, psikologi Islam merupakan ilmu yang membahas tentang manusia, terutama terkait kepribadian manusia, yang berisi filsafat, teori, metodologi, dan pendekatan permasalahan dengan didasari sumber-sumber formal Islam, akal, indera, dan intuisi. Bastaman mendefinisikan psikologi Islam dengan corak psikologi berdasarkan citra manusia menurut ajaran Islam, yang mempelajari keunikan dan pola perilaku manusia sebagai ungkapan pengalaman interaksi dengan diri sendiri, lingkungan sekitar, dan alam kerohanian, dengan tujuan meningkatkan kesehatan mental dan kualitas keberagamaan. Dengan demikian dapat disimpulkan bahwa psikologi Islam merupakan pandangan Islam terhadap ilmu psikologi modern dengan berbagai aspek. Psikologi Islam adalah usaha untuk membangun sebuah teori dari khazanah kepustakaan Islam, baik dari alQuran, Hadits, maupun kitab-kitab klasik yang ditulis oleh ulama-ulama Islam popular sehingga memberikan warna pada dunia psikologi yang saat ini terus berkembang pesat.

Pengkajian psikologi agama di dunia Timur (Islam) telah dikenal sebelum dunia barat mengkajinya. Hal ini dapat dibuktikan melalui beberapa karya fenomenal ilmuwan muslim yang mengkaji terkait dinamika keagamaan dan psikologi seseorang, di antaranya adalah karya Ibnu Thufail (1110-1185) dan al-Ghazali (1059-1111). Karya yang berjudul Hayn Ibn Yazan yang ditulis oleh Ibnu Tufail membahas masalah proses pertumbuhan dan perasaan agama dari seorang anak yang dilahirkan di pulau terpencil. Adapun karya Al-Ghazali yang berjudul al-Munqiz Mina al-Dholal (penyelamat dari kesesatan) banyak membahas tentang dimensi psikologi dan keagamaan seseorang.

Dalam Psikologi Islam terdapat beberapa hal yang dianggap penting, pertama bahwa psikologi Islam menitik beratkan pada aspek pengaruh. Dengan demikan, ada yang menyebut bahwa psikologi Islam sebagai ilmu pengaruh, yaitu ilmu yang mempelajari sikap dan perilaku seseorang sebagai hasil pengaruh dari keyakinan atau kepercayaan agama yang dianutnya. Kedua bahwa psikologi Islam mengkaji proses terjadinya pengaruh suatu kepercayaan atau keyakinan dalam menumbuhkembangkan jiwa keagamaan seseorang. Ketiga bahwa psikologi Islam mengkaji "kondisi" keagamaan seseorang. Apabila terjadi kemantapan ataupun kegoncangan jiwa dalam keberagamaannya juga menjadi objek kajian penting dalam psikologi Islam.

Psikologi Islam sebenarnya telah muncul sejak masa Islam awal yang disebut dengan periode Klasik. Periode ini dimulai pada masa Nabi Muhammad saw. Namun pada saat itu pembahasan psikologi Islam hanya berkisar kepada pembahasan tentang nafs atau jiwa, yang menghasilkan dua kelompok $^{6}$. Periode berikutnya yaitu periode modern dimulai pada tahun 1950-

${ }^{6}$ Kelompok pertama merupakan generasi ulama awal yang membahas tentang nafs atau jiwa semata-mata hanya bersumber dari al-Quran dan Hadits dan berlangsung sejak zaman Nabi Muhammad saw hingga masa Daulah Bani Umayyah. Kelompok ini nantinya akan 
an di Amerika yang ditandai dengan munculnya gerakan psikologi Islam yang muncul karena adanya dorongan tuntutan nyata untuk menghadapi krisis yang dihadapi umat manusia. Pada tahun 1978, diadakan Symposium on Psychology and Islam di Riyadh. Hal ini menandakan adanya perkembangan dari psikologi Islam itu sendiri. Di Indonesia, psikologi Islam juga mengalami perkembangan?

Berbicara mengenai perkembangan psikologi Islam di Indonesia, seorang tokoh bernama Zakiah Daradjat merupakan ilmuwan yang sangat berperan besar dalam mengenalkan dan mengembangkan psikologi Islam di Indonesia. Rektor UIN Syarif Hidayatullah Jakarta Komaruddin Hidayat menyebutkan bahwa Zakiah Daradjat merupakan pelopor psikologi Islam di Indonesia. ${ }^{8}$ Wanita yang dilahirkan di Bukittinggi, Sumatera Barat ini pada sebuah sumber disebutkan sebagai tokoh awal yang berasal dari kalangan santri yang mengenalkan psikologi Islam di Indonesia, dengan demikian, ia dikenal sebagai seorang psikolog muslimah di Indonesia. Tidak hanya sampai di situ, Zakiah Daradjat juga berhasil dinobatkan sebagai guru besar di UIN Syarif Hidayatullah Jakarta dan pernah menjabat sebagai Direktur Pasca Sarjana UIN Sunan Kalijaga Yogyakarta.

Zakiah Daradjat yang merupakan lulusan dari Universitas di Kairo, Mesir ini kemudian menjadi dosen luar bisa di banyak universitas di Indonesia, seperti IAIN Ar-Raniry (Aceh), IAIN Raden Patah (Palembang), dan beberapa universitas lainnya. Berkiprah di bidang pendidikan, wanita kelahiran 6 November 1926 ini juga aktif dalam kegiatan-kegiatan Departemen Agama. selain kegiatan-kegiatan ilmiah yang bertaraf nasional dan internasional, ia juga aktif dalam menulis karya-karya tulis fenomenal yang berorientasi pada pembahasan terkait Psikologi Islam dan pendidikan Islam.

Zakiah Daradjat berpendapat bahwa psikologi Islam dapat dijadikan sebagai pendekatan dalam pendidikan Islam. Kedua hal ini ditujukan untuk menciptakan para siswa yang memiliki kesehatan mental yang akan berlandaskan kepada agama, iman, dan takwa. Dengan demikian, hal ini akan memperlancar terwujudnya visi dan misi dari penyelenggraan pendidikan

berkembang menjadi ilmu kalam dan tasawuf. Adapun salah satu tokoh yang berasal dari kelompok ini adalah Imam Ghazali. Kelompok kedua muncul pada masa pemerintahan Abbasiyah. Kelompok ini tidak hanya menjadikan al-Quran dan Hadits sebagai landasan dari jiwa, melainkan juga menggunakan filsafat Yunani sebagai landasan dari pembahasan terkait jiwa. Hal ini merupakan dampak dari maraknya gerakan penerjemahan yang dilakukan pada masa itu. Lihat Erma Yudiani, "Pengantar Psikologi Islam", dalam, JIA, Nomor 2/Th. XIV, Desember 2013, hlm. 176-177.

7Perkembangan psikologi Islam di Indonesia ditandai dengan bermunculannya jurnaljurnal psikologi Islam, seperti Jurnal Pemikiran Psikologi Islam KALAM di Universitas Gadjah Mada dan Simposium Nasional Psikologi Islami di Universitas Muhammadiyah Surakarta pada tahun 1996. Selain jurnal, buku-buku yang berkaitan dengan pemikiran psikologi Islam juga gencar diterbitkan. Lihat Ibid.

8Zakiyatul Fitri, "Pemikiran Prof. Dr. Zakiah Daradjat, M.A Tentang Pendidikan Moral (Analisis Buku Membina Nilai-NIlai Moral di Indonesia)", Skripsi Program Studi Pendidikan Agama Islam Fakultas Tarbiyah dan Ilmu Keguruan Institut Agama Islam Negeri (IAIN) Salatiga, 2016, hlm. 17. 
Islam itu sendiri. Berdasarkan hal tersebut, maka terlihat jelas bahwa adanya keterkaitan erat antara psikologi Islam, pendidikan Islam, dan kesehatan mental dalam pemikiran Zakiah Daradjat.

Berdasarkan pemarapan di atas, maka penting untuk membahas lebih jauh terkait Sejarah Pemikiran Psikologi Islam oleh Zakiah Daradjat yang bertujuan untuk memaparkan dan menganalisa pemikiran Psikologi Islam dalam pandangan seorang psikolog muslimah bernama Zakiah Daradjat.

\section{HASIL DAN PEMBAHASAN}

\section{Biografi Zakiah Daradjat}

Prof. Dr. Zakiah Daradjat merupakan seorang psikolog muslimah yang dilahirkan di Kampung Tanah Merapak, Kecamatan Ampek Angkek, Bukittinggi, Sumatera Barat. Anak dari Haji Daradjat Ibnu Husain yang bergelar Raja Ameh (Raja Emas) ini dilahirkan pada tanggal 6 November 1926 M. Ibunya bernama Hj. Rofi'ah Binti Abdul Karim. Ia merupakan anak pertama dari 11 bersaudara. Zakiah Daradjat wafat saat dirawat di rumah sakit UIN Syarif Hidayatullah Jakarta dan dimakamkan di kompleks pemakaman UIN Jakarta. Ia sempat mengalami kritis dan menjalani perawatan di RS Hermina, Jakarta Selatan, pada pertengahan Desember 2012 hingga akhirnya meninggal dunia pada 15 Januari 2013 pukul 09.00 WIB.

H. Daradjat Husein merupakan seorang aktivis Muhammadiyah di Bukittinggi saat itu. Sedangkan ibunya merupakan aktivis dari Partai Syarikat Islam Indonesia di Padang. Kedua organisasi ini merupakan organisasi yang cukup disegani di kalangan masyarakat saat itu karena kiprahnya dalam memperjuangkan kemerdekaan Indonesia dan pendidikan. Keadaan tersebut menjadikan Zakiah sebagai seorang wanita yang memiliki wawasan sosial dan keagamaan serta memiliki prestasi khusus di bidang akademik. Adapun nilainilai keislaman yang tertanam di dalam dirinya terbentuk dari keadaan masyarakat tempat tinggalnya saat itu yang sangat agamis.

Jenjang pendidikan awalnya ia tempuh di sekolah Standard School (SD) Muhammadiyah yang terletak di tanah kelahirannya. Setelah itu ia melanjutkan pendidikannya ke jenjang SMP. Pada tahun 1947, ia menyelesaikan pendidikannya di sekolah Kuliyatul Mubalihgat Muhammadiyah di Padang Panjang, kemudian ia melanjutkan ke salah satu sekolah menengah atas (SMA) B TDR (Ilmu Pengetahuan Alam) pemuda Bukittinggi, dan berhasil menamatkan pendidikannya di sekolah tersebut pada tahun $1951 .{ }^{9}$

Setelah berhasil menamatkan pendidikannya di jenjang SMA, Zakiah pergi merantau ke Yogyakarta untuk melanjutkan pendidikannya dengan gelar Doktoral Satu (BA). Terhitung sejak tahun 1951 ia menimba ilmu di Fakultas Tarbiyah PTAIN Yogyakarta, dan berhasil menyelesaikan pendidikannya pada tahun 1956. Setelah berhasil menyelesaikan pendidikannya di PTAIN tersebut, ia mendapatkan besiswa dari Departemen Agama (DEPAG) untuk melanjutkan 
pendidikannya ke Mesir. Zakiah Daradjat melanjutkan pendidikannya di Ein Shame University Cairo di Mesir dengan jurusan Special Diploma For Education di Fakultas Pendidikan dan berhasil menamatkan pendidikannya pada tahun 1958. Tidak berhenti sampai di situ saja, Zakiah melanjutkan pendidikannya di jenjang Magister Pendidikan dengan jurusan "Spesialisasi dalam Mental Hygiene" yang berhasil ia selesaikan pada tahun 1958. Setelah itu, ia melanjutkan pendidikannya ke tingkat Doktor (Ph. D) Pendidikan, dengan jurusan Spesialiasi Psycho-Terapy, dan selesai pada tahun 1964. ${ }^{10}$ Adapun Disertasinya berjudul Dirasah Tajribiyah Li Taghayyur Al Lati Tathrau ala Syakhshiyat al Athfal al Musykil Infi 'al fi Khilal Fithrah al Ilaj al Nafs Ghair al Muwajjah an Thariq al La'b yang iakerjakan di bawah bimbingan Mustafa Fahmi dan Attia Mahmoud Hanna. ${ }^{11}$ Selama menjalani pendidikan S2, ia mulai mengenal klinik kejiwaan, bahkan sering berlatih praktek konsultasi psikologi di klinik universitas tersebut. Keberhasilan Zakiah Daradjat meraih gelar MA di luar negeri menjadi satu nilai lebih dari dirinya. Hal itu dikarenakan ia termasuk ke dalam generasi pertama Indonesia “dari kalangan santri" yang berhasil meraih gelar sarjana di luar negeri dalam bidang psikologi.

Setelah menyelesaikan pendidikannya di luar negeri, Zakiah Daradjat kembali ke Indonesia. Sejak saat itu, ia aktif berkiprah bersama Departemen Agama. Berikut ini merupakan kegiatan-kegiatan pengalaman kerja Zakiah Daradjat di lingkungan Departemen Agama:

1. Pegawai pada Perguruan Tinggi Agama dan pesantren Luhur (19641967)

2. Direktur Direktorat Pendidikan Agama (1972-1977)

3. Direktur Direktorat Pembinaan Perguruan Tinggi Agama Islam (1977-1984)

4. Anggota Dewan Pertimbangan Agung R.I (1983)

Selain itu, Zakiah Daradjat aktif mengajar sebagai Dosen Luar Biasa di beberapa universitas di Indonesia. Pada tahun 1965-1971 ia menjadi dosen luar biasa pada jurusan Kesehatan Mental di IAIN Syarif Hidayatullah (Jakarta), IAIN Ar-Raniry (Banda Aceh), IAIN Imam Bonjol (Padang), IAIN Raden Patah (Palembang), Universitas Islam Sumatera Utara (Medan), dan Institut Teknologi Bandung. Selain itu, ia juga menjadi dosen luar biasa pada bidang studi Ilmu Jiwa Agama pada tahun 1966-1972 di IAIN Syarif Hidayatullah, IAIN Gunung Djati, Universitas Islam Sumatera Utara, dan Pusat Pembinaan Mental Angkatan Bersenjata R.I. Zakiah Daradjat juga pernah menjadi dosen luar biasa pada jurusan Ilmu Jiwa Anak dan Ilmu Jiwa Sosial pada tahun 19661971 di IAIN Syarif Hidayatullah. Pada tahun 1986 ia diangkat menjadi

10Zakiah Daradjat, Kesehatan Mental, Peranannya dalam Pendidikan dan Pengajaran, disampaikan pada upacara pengukuhan Guru Besar Tetap dalam Ilmu Jiwa pada IAIN Syarif Hidayatullah Jakarta, 27 Agustus 1984, hlm. 63.

${ }^{11}$ Abuddin Nata, Tokoh-Tokoh Pembaruan Pendidikan Islam di Indonesia (Jakarta: PT. Raja Grafindo Persada, 2005), hlm. 235. 
Direktur Pasca Sarjan IAIN Sunan Kalijaga Yogyakarta dan ditetapkan sebagai guru besar dalam bidang Ilmu Jiwa Agama di IAIN tersebut.

Tidak hanya berkiprah dalam bidang pendidikan dengan menjadi dosen luar biasa saja, Zakiah Daradjat juga berkiprah dalam kegiatan-kegiatan ilmiah. Setidaknya tercatat sebanyak 140 kali kegiatan ilmiah berskali nasional dan 22 kali kegiatan ilmiah berskala internasional yang pernah ia ikuti. Di antaranya adalah sebagai pendiri dan ketua Yayasan Islam"Ruhama" di Jakarta (1983) dan pendiri sekaligus ketua yayasan kesejahteraan mental Bina Amalah di Jakarta (1990). Di bidang pendidikan Indonesia, Zakiah Daradjat juga memiliki andil besar. Salah satunya adalah ketika dikeluarkannya Surat Keputusan Bersama Tiga Menteri (SKB Tiga Menteri) yang mengantarkan kepada terjadinya perubahan dalam pendidikan madrasah, yaitu dimasukkannya pengetahuan umum sebanyak $70 \%$ dan pengetahuan agama sebanyak $30 \%$. Dengan demikian kurikulum madrasah mengalami perubahan yang sangat signifikan dan lulusan-lulusannya pun dapat diterima di perguruan-perguruan tinggi di Indonesia. ${ }^{12}$

Sebagai seorang ilmuan, Zakiah Daradjat telah berhasil menciptakan beberapa karya ilmiah fenomenal, baik dalam bidang pendidikan maupun dalam bidang psikologi Islam. Berikut ini merupakan beberapa karya ilmiah dari Zakiah Daradjat:

1. Kesehatan Mental (1969)

2. Peranan Agama dalam Kesehatan Mental (1970)

3. Ilmu Jiwa Agama (1970)

4. Pendidikan Agama dalam Pembinaan Mental (1970), dan beberapa karya lainnya.

5. Problem Remaja di Indonesia yang merupakan terjemahan dari tesisnya yang berjudul The Problems of Adolescence in Indonesia.

6. Membina nilai-nilai moral di Indonesia.

7. Remaja, harapan, dan tantangan.

Berdasarkan pemaparan biografi di atas, maka dapat dilihat bahwa Zakiah Daradjat merupakan seorang psikolog muslimah dari Indonesia yang berhasil membawa perubahan besar dalam bidang psikologi dan pendidikan Islam di Indonesia. hal tersebut terlihat dari perannya baik di bidang pendidikan maupun di bidang ilmiah lainnya melalui aktifitas ilmiah maupun karya-karyanya. 


\section{Psikologi Islam dalam Pemikiran Zakiah Daradjat}

Istilah psikologi Islam di Indonesia sudah mulai dikenal sejak tahun 1970-an, yang pertama kali diperkenalkan oleh Prof. Dr. Zakiah Dardjat dan Prof. Dr. A. Mukti Ali, terutama di lingkungan IAIN dan perguruan tinggi Islam lainnya. Menurut Zakiah Daradjat, psikologi Islam adalah ilmu yang meneliti pengaruh agama terhadap sikap dan tingkah laku seseorang atau mekanisme yang bekerja dalam diri seseorang yang menyangkut cara berfikir, bersikap, bereaksi, dan bertingkah laku, yang tidak terpisahkan dari keyakinannya, karena keyakinan itu masih dalam konstruk kepribadiannya. ${ }^{13}$

Menurut Zakiah Daradjat aspek yang membedakan antara psikologi kontemporer dengan psikologi Islam terletak pada rumusan konsep manusia dan dalam pendekatannya. Dalam pandangan psikologi kontemporer hanya mengandalkan kemampuan intelektual dalam menemukan dan mengungkap asas-asas kejiwaan, sementara dalam pandangan psikologi Islam mendekatinya dengan memfungsikan akal dan keimanan sekaligus. Lebih jauh, Zakiah Daradjat mengungkapkan bahwa ruang lingkup psikologi kontemporer hanya terbatas pada tiga dimensi, yaitu dimensi fisik-biologi, dimensi kejiwaan, dan dimensi sosiokultural. Sementara psikologi Islam juga mencakup dimensi kerohanian dan spiritual suatu wilayah yang menajdi pantangan dan tidak pernah disentuh oleh psikologi kontemporer karena perbedaan landasan. Di sinilah psikologi Islam akan bertemu dengan tasawuf nantinya. ${ }^{14}$

Secara lebih jauh, Zakiah Daradjat memaparkan pendapatnya terkait pengertian psikologi itu sendiri. Ada beberapa pengertian psikologi Islam menurut Zakiah Daradjat, yaitu: ${ }^{15}$

1. Psikologi Islam adalah ilmu yang berbicara tentang manusia, terutama kepribadian manusia yang bersifat filsafat, teori, metodologi, dan pendekatan problem dengan didasari sumbersumber formal Islam (Al-Quran dan Hadits), akal, indera, dan intuisi.

2. Psikologi Islam merupakan konsep psikologi modern yang telah mengalami filterisasi dan di dalamnya terdapat wawasan Islam.

3. Psikologi Islami ialah perspektif Islam terhadap psikologi modern dengan membuang konsep-konsep yang tidak sesuai atau bertentangan dengan Islam.

4. Psikologi Islam adalah ilmu tentang manusia yang kerangka konsepnya benar-benar dibangun dengan semangat Islam dan berdasarkan sumber formal (Al-Quran dan Hadits) yang dibangun dengan memenuhi syarat-syarat ilmiah.

${ }^{13}$ Ikhrom, "Titik Singgung Antara Tasawuf, Psikologi Agama, dan Kesehatan Mental", dalam Jurnal Teologia, Volume 19, Nomor. 1, Januari 2008, hlm. 5.

${ }^{14}$ Erma Yudiani, "Pengantar Psikologi Islam", dalam JIA, Nomor 2/Th.XIV, Desember 2013, hlm. 180-181.

${ }^{15}$ Ibid. 
5. Psikologi Islam adalah corak psikologi yang berlandasakan citra manusia menurut ajaran Islam, yang mempelajari keunikan dan pola prilaku manusia sebagai ungkapan interaksi dengan diri sendiri dan alam keruhanian dengan tujuan meningkatan kesehatan mental dan kualitas keberagamaan.

Berdasarkan pemaparan tersebut, maka dapat dilihat bahwa psikologi Islam mengandung beberapa unsur penting, yaitu:

1. Bahwa psikologi merupakan salah satu dari kajian-kajian masalahmasalah keislaman yang memiliki kedudukan yang sama dengan disiplin ilmu lainnya. adapun penggunaan kata "Islam" berarti corak, cara pandang, pola piker, paradigm atau aliran,yang berarti bahwa psikologi yang dibangun memiliki pola piker sebagaimana yang berlaku pada tradisi keilmuan dalam Islam, sehingga dapat membentuk aliran tersendiri yang unik dan berbeda dengan psikologi kontemporer pada umumnya.

2. Psikologi Islam membicarakan terkait aspek-aspek dan perilaku kejiwaaan manusia dan hakikat jiwa sesungguhnya.

3. Psikologi Islam bukanlah ilmu netral etik, melainkan sarat akan nilai etik. Hal tersebut dikarenakan tujuan hakiki dari psikologi Islam adalah merangsang kesadaran diri agar mampu membentuk kualitas diri yang lebih sempurna untuk mendapatkan kebahagiaan hidup di dunia dan akhirat.

Psikologi Islam menurut Zakiah Daradjat berkaitan erat dengan pendidikan Islam. Ia mengutarakan bahwa terjadinya fenomena-fenomena yang tidak lazim di dunia pendidikan Indonesia mengindikasikan adanya gangguan jiwa (kesehatan mental yang mengalami gangguan) yang terjadi pada mayoritas masyarakat Indonesia. Gangguan jiwa tersebut tidak disebabkan karena kerusakan organik pada tubuh, melainkan karena kondisi jiwa merasa tertekan, kecewa, gelisah, was-was, dan sebagainya.

Oleh karena itu, di sinilah agama dan pendidikan Islam memainkan peran pentingnya, yaitu untuk mengatasi masalah-masalah gangguan jiwa tersebut. Menurut Zakiah, agama memiliki peran yang sangat mendasar dalam memahami esensi kejiwaan manusia. Pengaruh keyakinan agama diyakini oleh seseorang akan berimplikasi kepada perilakunya. Oleh karena itu agama dapat dijadikan sebagai dasar pijakan psikologi. Kemudian melalui jalur pendidikan Islam akan dibahas terkait proses bimbingan, arahan, pengajaran, dan pembinaan, terhadap peserta didik yang akan dimulai dari lingkungan keluarga.

Pemaparan tersebut membuktikan adanya saling keterkaitan antara pendidikan Islam dengan psikologi agama. Dalam hal ini, psikologi agama dijadikan sebagai pendekatan untuk menyampaikan visi dan misi yang diusung oleh pendidikan Islam. Psikologi agama juga memiliki peranan 
penting dalam kesehatan mental, dengan cara meneliti, menelaah, mempelajari, dan mengkaji pengaruh agama terhadap sikap dan tingkah laku seseorang atau mekanisme yang bekerja dalam diri seseorang, karena cara berfikir, bersikap, dan bereaksidan bertingkah laku yang tidak dapat dipisahkan dari keyakinanya, sebab keyakinan itu terkategori dalam konstruksi kepribadiannya. Dengan begitu, seseorang akan terhindar dari gejala-gejala gangguan jiwa dan penyakit jiwa.

Dalam hal ini, agama memiliki peran yang sangat urgent yang berfungsi sebagai terapi bagi jiwa yang gelisah dan terganggu, sebagai alat penegah terhadap kemungkinan gangguan kejiwaan. Sebab agama memberikan berbagai pedoman dan petunjuk agar memperoleh ketentraman jiwa dan bimbingan hidup di segala bidang. Adapun pendidikan Islam merupakan jalur yang ditempuh untuk membimbing, mengarahkan, mendidik, dan membina peserta didik, terutama bagi peserta didik yang mengalami gangguan mental. ${ }^{16}$

Berdasarkan pemaparan di atas, dapat diketahui bahwa kesehatan mental ${ }^{17}$ seseorang dalam pandangan psikologi agama merupakan aspek yang sangat penting. Menurut Zakiah Daradjat kesehatan mental adalah terwujudnya keserasian yang sungguh-sungguh antara fungsi-fungsi kejiwaan dan terciptanya penyesuaian diri sendiri antara manusia dengan dirinya sendiri dan lingkungannya, berlandaskan keimanan dan ketaqwaan, serta bertujuan untuk mencapai hidup yang bermakna bahagia di dunia dan akhirat. ${ }^{18}$ Untuk dapat menyesuaikan diri dengan diri sendiri, seseorang harus lebih mengenal dirinya dan menerima sebagaimana adanya. ${ }^{19}$

Zakiah Daradjat berpendapat bahwa kesehatan mental adalah bentuk personifikasi dari iman dan takwa seseorang. Ini difahami bahwa semua kriteria kesehatan mental yang dirumuskan harus mengacu kepada nilai-nilai iman dan takwa. Bila kesehatan mental berbicara tentang integritas kepribadian, realisasi diri, aktualisasi diri, penyesuaian diri, dan pengendalian diri, maka parameternya harus merujuk kepada iman dan takwa, akidah, dan syariat. ${ }^{20}$ Terganggunya kesehatan mental seseorang dapat mempengaruhi terhadap aspek-aspek kehidupan orang tersebut. Pengaruh tersebut diklasifikasikan ke dalam empat bagian, yaitu: perasaan, pikiran/kecerdasan,

16Iwan Janu Kurniawan, “Pemikiran Prof. Dr. Zakiah Daradjat Tentang Pendidikan Islam dalam Perspektif Psikologi Agama", Skripsi Fakultas Agama Islam, Universitas Muhammadiyah Surakarta, 2012, hlm. 21-22.

${ }^{17}$ Kesehatan mental terdiri dari dua kata, yaitu kesehatan dan mental. Kesehatan memiliki kata dasar "sehat" mendapat awalan ke- dan akhiran -an, menyatakan hal atau keadaan. Adapun sehat berarti bebas dari rasa sakit. Dengan demikian, kesehatan berarti keadaan badan seseorang yang tidak sakit. Mental berasal dari bahasa Latin, yaitu mens, mentil, yang berarti jiwa, roh, sukma, nyawa, dan semangat. Lihat Kartini Kartono dan Jenny Andri, Hygiene Mental dan Kesehatan Mental dalam Islam (Bandung: Mandar Maju, 1989), hlm. 3.

${ }^{18}$ Yahya Jaya, Peranan Taubat dan Manfaat dalam Kesehatan Mental (Jakarta: Yayasan Pendidikan Islam Ruhana, 1992), hlm. 15.

19Zakiah Daradjat, Kesehatan Mental (Jakarta: PT. Toko Gunung Agung, 1995), hlm. 11.

${ }^{20} \mathrm{IKhrom}$, hlm. 8 
kelakuan, dan kesehatan badan. ${ }^{21}$ Sementara itu, ia mengutarakan bahwa ada beberapa faktor yang mempengaruhi terganggunya kesehatan mental seseorang, yaitu: rasa cemas, iri hati, sedih, merasa rendah diri, pemarah, ragu, dan sebagainya. Faktor lainnya yang juga sangat berpengaruh adalah faktor lingkungan, seperti lingkungan keluarga, lingkungan masyarakat, dan lingkungan sekolah. ${ }^{22}$

Zakiah Daradjat berpendapat bahwa ada empat indikator yang dapat digunakan untuk melihat tingkat kesehatan mental seseorang, yaitu:

1. Ketika seseorang mampu menghindarkan diri dari gangguan mental (Neurose) dan penyakit (Psikose).

2. Ketika seseorang mampun menyesuaikan diri dengan masyarakat, alam, dan Tuhan.

3. Ketika seseorang mampu mengendalikan diri terhadap semua masalah dan keadaan kehidupannya sehari-hari.

4. Ketika dalam diri seseorang terwujud keserasian, dan keharmonisan antara fungsi-fungsi kejiwaan.

Dengan adanya indikator tersebut, maka seseorang akan dapat dengan mudah mengukur tingkah kesehatan mentalnya, dengan asumsi bahwa semakin terpenuhinya keempat indicator tersebut, maka semakin tinggi pula tingkat kesehatan mental seseorang, dan berlaku pula sebaliknya. Karena itulah, Zakiah Daradjat menyebut "bahasan kesehatan mental dengan empat indicator" dengan istilah "kesehatan mental sebagai kondisi kejiwaan seseorang". Di samping terdapat dua istilah, yaitu kesehatan mental sebagai ilmu pengetahuan dan kesehatan mental sebagai terapi kejiwaan atau bentuk psikoterapi.

Dalam proses penentuan corak kepribadina seseorang, terdapat beberapa unsur penting, yaitu nilai-nilai yang diambil dari lingkungan, terutama lingkungan keluarga. Nilai-nilai yang dimaksud adalah nilai agama, moral, dan sosial. Di antara ketiga nilai-nilai tersebut, nilai agama merupakan nilai yang bersifat positif dan tetap serta tidak berubah-ubah. Sedangkan nilai sosial dan moral yang tidak dilandaskan pada agama akan sering mengalami perubahan sesuai dengan perkembangan masyarakat itu sendiri. Oleh sebab itu, mental (kepribadian) yang hanya terbina dari nilai-nilai sosial dan moral akan besar kemungkinan terjadinya perubahan dan goncangan tersebut akan membawa kepada kegoncangan jiwa, apabila terjadi perubahan. Dengan demikian, seseorang yang mengalami kegoncangan jiwa akan cenderung memiliki peluang lebih besar untuk mengalami gangguan kesehatan mental. ${ }^{23}$ Di sinilah titik temu dan pentingnya agama dalam pembinaan kesehatan

\footnotetext{
${ }^{21}$ Susilawati, "Kesehatan Mental Menurut Zakiah Daradjat", Skripsi Fakultas Dakwah dan Ilmu Komunikasi Universitas Islam Negeri Raden Intan Lampung, 2017, hlm. 82.

${ }^{22}$ Zakiah Daradjat, Kesehatan Mental Peranannya dalam Pendidikan dan Pengajaran (Jakarta: Institut Agama Islam Negeri Syarif Hidayatullah, 1984), hlm. 17.

${ }^{23}$ Zakiah Daradjat, Peranan Agama dan Kesehatan Mental (Jakarta: PT. Gunung Agung, 1978), hlm. 90.
} 
mental yang dikemukakan oleh Zakiah Daradjat dalam pandangannya mengenai psikologi Islam.

Berdasarkan pemaparan di atas, maka dapat diketahui bahwa psikologi Islam dalam pandangan Zakiah Daradjat memiliki kaitan yang sangat erat dengan pendidikan Islam dan kesehatan mental. Psikologi Islam digunakan sebagai pendekatan dalam pendidikan Islam untuk memperlancar visi dan misi dari penyelenggaraan pendidikan Islam itu sendiri. Psikologi Islam juga digunakan untuk meminimalisir keadaan yang tidak seharusnya terjadi di dunia pendidikan saat ini, seperti sikap membantahnya seorang murid kepada gurunya dan lain-lain. Hal itu digunakan untuk menciptakan manusia dengan tingkat kesehatan mental yang baik, yaitu manusia yang bertindak sesuai dengan ajaran agama yang ia yakini.

\section{PENUTUP}

Berdasarkan pemaran di atas, maka dapat ditarik beberapa kesimpulan, yaitu:

1. Psikologi Islam lahir sebagai reaksi terhadap kehadiran dan perkembangan psikologi umum yang bersifat netral etik dan dijadikan sebagai "alat analisa" terhadap kehidupan muslim yang syarat etik.

2. Masuk dan berkembangnya psikologi Islam itu sendiri ke Indonesia salah satunya adalah dipelopori oleh Zakiah Daradjat. Ia merupakan seorang psikolog muslimah yang dilahirkan di Bukittinggi, Sumatera Barat pada tanggal 6 November 1926 M. Anak pertama dari sebelas bersaudara ini mengawali pendidikannya di tanah kelahirannya, dan terus melanjutkan pendidikannya hingga mencapat gelar Doktor (Ph. D) di salah satu universitas di Kairo. Setelah menyelesaikan pendidikannya, ia kembali ke Indonesia dan mulai aktif mengajar di perguruan tinggi negeri dan universitas-universitas sebagai dosen luar biasa. Ia juga pernah menjadi direktur pasca sarjana UIN Sunan Kalijaga Yogyakarta dan juga dikukuhkan sebagai guru besar.

3. Selain aktif di bidang pendidikan, Zakiah Daradjat juga aktif menulis karya-karya ilmiah yang berorientasi pada pembahasan psikologi Islam dan pendidikan Islam. Dalam bidang pendidikan, salah satu kontribusi besar yang ia sumbangkan adalah ketika dikeluarkannya Surat Keputusan Bersama oleh 3 menteri yang pada akhirnya berimbas pada diubahnya kurikulum pendidikan di madrasah. Selain itu, wanita yang meninggal dan dimakamkan di komplek pemakaman UIN Syarif Jakarta ini juga aktif dalam kegiatan-kegiatan ilmiah baik di tingkat nasional dan internasional. Ia juga aktif dalam kegiatan di lingkungan Departemen Agama.

4. Psikologi Islam dalam pandangan Zakiah Daradjat adalah ilmu yang meneliti pengaruh agama terhadap sikap dan tingkah laku seseorang atau mekanisme yang bekerja dalam diri seseorang yang menyangkut cara berfikir, bersikap, bereaksi, dan bertingkah laku, yang tidak 
terpisahkan dari keyakinannya, karena keyakinan itu masih dalam konstruk kepribadian seseorang.

5. Psikologi Islam dalam pandangan Zakiah Daradjat berkaitan erat dengan pendidikan Islam dan kesehatan mental. Psikologi Islam dijadikan sebagai pendekatan dalam pendidikan Islam untuk menciptakan orang-orang yang memiliki kesehatan mental. Dengan demikian, hal-hal yang tidak seharusnya terjadi di lingkungan pendidikan akan dapat diperbaiki.

\section{REFERENSI}

Bainar, H. Kiat Sukses Wanita Indonesia. Jakarta: Perkasa Press, 1997.

Daradjat, Zakiah. Islam dan Kesehatan Mental. Jakarta: PT. Gunung Agung, 1982. - Kesehatan Mental (Peranannya dalam Pendidikan dan Pengajaran). Jakarta: Institut Agama Islam Negeri, 1984. . Ilmu Jiwa Agama. Jakarta: Bulan Bintang, 2005. . Kesehatan Mental. Jakarta: PT. Toko Gunung Agung, 1995. . Peranan Agama dalam Kesehatan Mental. Jakarta: Gunung Agung, 1970.

F. Brennan, James. History And System of Psychology, diterjemahkan oleh Nurmala Sari Fajar, Sejarah dan Sistem Psikologi. Jakarta: Raja Wali Pers, 2006.

Fitri, Zakiyatul. “Pemikiran Prof. Dr. Zakiah Daradjat, M.A Tentang Pendidikan Moral (Analisis Buku Membina Nilai-NIlai Moral di Indonesia)". Skripsi Program Studi Pendidikan Agama Islam Fakultas Tarbiyah dan Ilmu Keguruan Institut Agama Islam Negeri (IAIN) Salatiga, 2016.

Hidayati, Bahril. "Psikologi Islam". Fakultas Psikologi Universitas Negeri Sultan Syarif Pekanbaru-Riau, 2014.

Ikhrom. “Titik Singgung Antara Tasawuf, Psikologi Agama, dan Kesehatan Mental". Dalam Jurnal Teologia, Volume 19, Nomor. 1, Januari 2008.

Jaya, Yahya. Peranan Taubat dan Manfaat dalam Kesehatan Mental. Jakarta: Yayasan Pendidikan Islam Ruhana, 1992.

Kartono, Kartini dan Jenny Andri. Hygiene Mental dan Kesehatan Mental dalam Islam. Bandung: Mandar Maju, 1989.

Kurniawan, Iwan Janu. "Pemikiran Prof. Dr. Zakiah Daradjat Tentang Pendidikan Islam dalam Perspektif Psikologi Agama". Skripsi Fakultas Agama Islam, Universitas Muhammadiyah Surakarta, 2012.

Mujib, Abdul dan Yusuf Mudzakir. Nuansa-Nuansa Psikologi Islam. Jakarta: Rajawali Pers, 2002.

Nasution, Harun. Islam Ditinjau Dari Berbagai Aspek Jilid I. Jakarta: UI Press, 2011. 
Nata, Abuddin. Tokoh-Tokoh Pembaruan Pendidikan Islam di Indonesia. Jakarta: PT. Raja Grafindo Persada, 2005.

Susilawati. "Kesehatan Mental Menurut Zakiah Daradjat". Skripsi Fakultas Dakwah dan Ilmu Komunikasi Universitas Islam Negeri Raden Intan Lampung, 2017

Yudiani, Erma. "Pengantar Psikologi Islam". Dalam, JIA, Nomor 2/Th. XIV, Desember 2013. 